IIUC STUDIES

ISSN 1813-7733

Vol.- 7, December 2010

(Published in December 2011) (p 147-178)

\title{
Identity of an Islamic Ideological State: An Analytical Study
}

\author{
Muhammad Rafiqul Hoque*
}

\begin{abstract}
The Islamic system of state established by the Prophet (SM), existed from 623CE in Medina. The state of Medina was neither monarchic nor republican, ruled on the policy of the majority. This state was based neither on tribalism nor on nationalism, rather on humanism and Islamic monotheism. It was really an Ideological state and the ideology was Islam. In the present paper, an attempt has been made to describe the main features of an Islamic Ideological state through its main principles and distinguishing points of three basic organs and to analyse the differences between an Islamic state and secular states.
\end{abstract}

\section{Introduction}

"Verily! Allah commands that you should render back the trusts to those to whom they are due; and that when you judge between men, you judge with justice. Verily, how excellent is the teaching, which He gives you. Truly, Allah is Ever All hearer and All -Seer. O you who believe! Obey Allah and obey the Messenger and those of you who are in authority. If you differ in anything amongst yourselves, refer it to Allah and the Messenger, if you believe in Allah and in the last Day. That is better and more suitable for final determination". 1 (An Nisa: 58-59).

In the light of this expression, the Islamic state is not only a system of leadership and ruling ordained by Allah so as to take care of the Muslim and to judge among the people with truth according to the Qur'an and the Sunnah, but it is also the political entity, which brings

\footnotetext{
* Lecturer in Islamic Studies, Center for University Requirement Courses (CENURC), IIUC.
} 
all of the Islamic systems into application that establishes peace, safeguards and propagates the Islamic way of life.

This Islamic system of state, established by the Prophet Mohammad (SM) and followed by his immediate successors, existed from the time of the establishment of Islam 1400 years ago. After the rightly guided Khalifas, the state turned into somewhat monarchic but was not derailed totally from its ideology and basic principles of Islam. At last with the end of the Ottoman regime, the Islamic state (Khilafah) was completely destroyed by Mustafa Kamal in 1924CE. The capital city of the Khilafah at the time of its demise was Istanbul ${ }^{2}$. There is reason to believe that if this kind of state is established again, the whole humanity will get their much needed peace and happiness returned.

\section{Islam: An Introduction}

'Islam' is an Arabic word, having its root word 'Slm' pronounced (Silm or Salm) which means;

a. Submission, surrender, resignation (Silm)

b. Peace, security, tranquility etc. (Salm)

Considering the first meaning it is so named because 'Islam' is the religion of total submission to the will of Allah the Almighty, who is the Creator of this universe.

Considering the second meaning 'Islam' is so named because it guarantees for peace, tranquility and security to its followers to the society and the humanity at large.

Analyzing the literal meaning we may say, 'Islam is the religion of submission to the Almighty Allah (Swt) in its vertical relation between the man and his creator, and it is the religion of peace in its horizontal consideration, in relation to all other creation.

'Al-Islam' or 'Islam' is the religion which brings peace to mankind when man commits himself to Almighty Allah and submits himself to His will, according to the holy Book of Allah (al-Qur'an) which was revealed to Muhammad (SM). This is the only true religion professed by all Prophets from Adam to Muhammad (SM), the last of the chain of Prophethood. A Muslim is one who resigns himself to God and thereby professes the faith of al-Islam. A Muslim, therefore, believes in all Prophets and makes no distinction between one and the other. 
The teachings of Islam unlike other religions, deal not only the issues regarding belief and relating to metaphysics, but Islam does also deal with each and every issue which is related to human life down from his belief, behavior, attitude and interaction, in his personal, social, political, economic, cultural, moral and spiritual life, even it deals with all the issues related to life in this world and the life Hereafter. Islam has its very clear view and specific attitude regarding every aspect of life of a man.

\section{Islamic Shaari'ah}

The term Shari'ah, means the way or law. In Islamic terminology, it implies the way or road in Din which Allah has established for the guidance of mankind both for worship of Allah and duties of life, i.e. the detailed code of conduct and mode of worship. Allah says in the Qur'an:

"Then We have put you (O Muhammad) on (right) way of religion, so follow you it and follow not the whims of those who know not". $(45: 18)$

Shari'ah is the code of law for the Islamic way of life which Allah has revealed to His Messenger for mankind and commanded to follow.

The Shari'ah or Islamic law is based on two main sources: The Qur'an and Sunnah. It aims towards the success and welfare of mankind both in this life and in life after death.

Shari'ah prescribes a complete set of laws for the guidance of mankind so that Good (Ma'ruf) may triumph and the Evil (Munkar) disappear from the society. It provides a clear and straight path, which leads to progress and fulfillment in life and attainment of Allah's pleasure.

Shari'ah has two other sources: The Ijma (consensus) and the Qiyas (analogy or reasoning on the basis of similar circumstance). These sources must be based on the Qur'an and Sunnah. Ijma or consensus can be done in a situation when no clear evidence is available from the Qur'an and the Sunnah. In this situation, the Ulama work out an agreed formula to solve the particular problem. 
Qiyas is applied in a circumstance where evidence from the Qur'an and the Sunnah is not directly available. A solution to a problem is reached by a process of deduction from comparison with similar situations.

The Shari'ah has rules for every aspect of life. It is complete and perfect. It guarantees us success, welfare and peace in this life on the earth and in the life hereafter.

\section{Human action under Qur'anic Injunctions as the first source of Shari'ah:}

Just before we said that the Shari'ah has rules for every aspect of life. But for every action of human being, Islamic Shari'ah has its ruling. In a minute division, human actions under the Qur'anic Injunctions are classified into three categories.

- Firstly Al-Ahkam Al-I'etiqadyah (Faith and beliefs) - ruling related with faith and beliefs of a man, i.e. belief in the Unity of Allah, belief in the Angels of Allah, in the books of Allah, in the Messengers of Allah and belief in the life after death.

- Secondly al-Ahkam al khuluqiyah (Ethics and Moralities) that a man should be adorned with some good qualities and be devoid of some immoralities, and

- Thirdly al-'Amaliyat (Activities) that brought out from a man of his sayings, doings, making any treaties or agreements with other etc.

This 'Amaliyat, according to its nature, is also categorized into two parts.

1. First one is Ahkamul Ibadat (religious observance) like Salat, Sawm, Zakah, Hazz, Vows and others through which a man may make relation with his Creator to whom he is destined to return.

2. Second one is called al-Ahkamul Mu'amalat (Dealings and Behaviors) like contracts or agreements, behavioral tendencies, crimes and penalties etc. through which a man relates with other man individually or collectively and through which his relation with all that exists in this whole world other then Allah is determined. In Islamic terminology it is said Ahkamul Mu'malat but in our modern age this Ahkamul Mu'amalat are classified into various classification. These are as follow; ${ }^{3}$ 
1. Ahkamul Ahwal Ash shakhsiyah or personal Law

2. al-Ahkam al-Madaniyah or civil law

3. al-Ahkam al-Janeyah or criminal law

4. Ahkamul murafa'at or law of defense

5. al-Ahkam al-Dasturiyah or constitutional law

6. al-Ahkam al-Dawliyah or international law

7. al-Ahkam al-iqtisadiyah wa al-Maliyah or business and commercial law

It may be pointed out that the Holy Qur'an, as the first source of Islamic Shari'ah, has given detailed instructions only for first two categories (Al-Ahkam Al-I'etiqadyah and al-Ahkam al khuluqiyah) and of third category (Al-'Amaliyat) for Ibadat has also laws in the Qur'an in details.

Now regarding Mu'amalh, as almost every thing of it except some of Ahkamul Ahwalul al-Shakhsiyah, being subordinate to change and development of society, the holy Qur'an has laid down only border lines and basic principles according to which new laws on the basis of main sources of Shari'ah be brought up.

As for (Ahkamul Ahwalul al-Shakhsiyah) personal law- like marriage, divorce or inheritance etc., due to ignorance and emotion people may fall prey to wrong decision, Allah (Swt) has mercifully given the detailed instructions, and nothing is left here for men without implementation the instruction of Allah (Swt).

Through this long discussion of human action under Qur'anic Instructions, what we are to express that for identifying Islamic Ideological State, we should search for the broad principals and basic rules of the Qur'an, and observe how was it implemented and practiced in the life of the Prophet (Sam) and in the period of four rightly guided Khulafa and later. It may suit hare to get an idea about the philosophy of State and politics in Islam.

\section{Philosophy of Islamic State and Politics}

From time immemorial, numerous ideologies have come into existence; however, there is no concordance with one another, because one doctrine comes into being challenged by other ideologies. This is because those who are the originators of these doctrines, their belief, 
thoughts, feelings and nature are totally different from one another. Aftermath, the people are experiencing dire consequences because of the man-made ideologies.

The one and only remedy for these complex circumstances, is to believe that there is none to be worshiped, not a single one whose order may be abided by in the cosmos but Allah. He who created the whole world and everything in it, alone is the Master, Sustainer and All powerful. He knows everything seen or unseen.

There is no loyalty in His deeds and thus His is the absolute right of giving directions and interdictions. And His system is undoubtedly far away from defect and blame. Human being is the khalifa or vice gerent of Allah. He has no right to make any doctrine or ideology; this right belongs to Allah alone who created him and made him subject to His will.

Therefore, Man has no duty in this world but to pay servitude to Allah and to put his orders into effect. His life in this world is meaningless and can never be successful unless he turns to be a pure servant of Allah, and follow His universal system in all aspects of life.

If we think over the creations of Allah, we can see that the whole world follows His universal system. Even in a human being, his body function is obedient to this universal system.

Since, the whole world and everything in it, living or non-living follows His universal system, we may define this universal system as His political system and the whole world as His State.

Among all the creatures to this universe, man is a creature of strange nature, wherein no other creature shares him. Human being are different in this respect that they are bestowed with freedom of will for accepting the truth and rejecting it, and that they have been entrusted with the office of the vicegerency or khilafah due to which whatever in this world, are subdued to them, they can use them according to their wish and need. In this regard Allah (SWT) has sent His messengers with clear guidance in order that His absolute kingdom may be established in the universe and the people abide by His laws willingly.

Therefore, the Islamic political system is unique one. It cannot resemble a federal, democratic, republican, monarchic or dictatorial system and the like at all. 
This system is far reaching and addresses all spheres of human activities from the smallest to the biggest. This considers people under its authority as its members, whether they are Muslim or non-Muslims. All have their rights guaranteed by Islam.

Allama Abul A'la al Maududi mentions Islamic politics is based on three fundamental elements ${ }^{4}$ Tawhid (Unity of Allah) Risalat (Prophethood) and khilafah (vicegerency).

Without comprehensive understanding of these three fundamental elements it is too refractory to comprehend the other imperative aspects of Islamic polity.

Hence, a brief exposition of these three momentous elements is given bellow.

Tawhid means Allah is the only Creator, Sustainer and Master of the universe and all that exist in it irrespective of whether they are organic or inorganic.

The sovereignty of this universe belongs only to Him and He alone has the right to command and forbid. Worship and obedience are due to Him alone, none can deserve sharing in it anyway. Life is in all its forms, our physical organs and faculties; none of them has been created by us.

These have been bestowed to us by Allah (SWT). Therefore, we have no right to determine the aim and purpose of our existence or to set the limits of our authority. No one else is entitled to make law.

These principles of the unity of Allah totally negate the concept of the legal and political independence of human beings, individually or collectively. No individual, family, class or race can set himself or herself above Allah. Allah alone is the Ruler and His commandments are the laws.

Risalat, this is the media through which we get the law of Allah. We are provided two things from this source; the Book of Allah (Kitab), and the tradition of Prophet (Sunnah). 
The former is the Book wherein Allah has delivered His law to us. The latter is Sunnah wherein the authoritative exposition and exemplifications of the divine Book are offered by the Prophet (SM) through words and deeds as he is the vicegerent of Allah,

Khilafah (vicegerency), its lexicological meaning is representation. In accordance with Islam, man is representative of Allah on this earth.

That is to say, by virtue of the power delegated to him by Allah, he is required to exercise his Allah-given authority in this world within the limits prescribed by Allah.

In this context, an example can be given. Suppose, I have an estate and someone has been appointed by me to administer as my representative. Then undoubtedly I would see the consolidation of following four conditions.

First, real ownership of the estate remains vested on me and not in the administrator.

Second, he administers my property only in accordance with my instructions.

Third, he exercises his authority within the limits prescribed by me

Fourth, in the administration of the trust he executes my will and not his own.

These four conditions are so inherent in the concept of representation that if any representative fails to observe them he will rightly be blamed for breaking the covenant, which was implied in the concept of representation.

This is exactly what Islam means when it affirms that man is the vicegerent of Allah on earth. Hence, these four conditions are also involved in the concept of Khilafah.

The state that is established in accordance with this political theory will in fact be a human caliphate under the sovereignty of Allah and will have to fulfill the purpose and intent of Allah by working on Allah's earth within the limits prescribed by Him and in conformity with instructions and injunctions. 
Necessity of Islamic State: The Muslim Ummah has come to realize that the solution to their problems rests on creating the Islamic state. Nevertheless The Islamic State is not a desire that one aims to satisfy, but an obligation that Allah (SWT) has decreed on Muslims and commanded them to execute.

Besides, Islam is a comprehensive way of life, which necessitates the existence of the State to implement the Shari'ah at individual and social level comprehensively. Individuals can abide by some rules of Islam related to the prayer, fasting, and Hajj. The other rules of Islam that organize the various political, social, economic, and international relationships, require the existence of the state with the authority to organize the myriad of relationships of the Ummah and to mobilize them towards propagating Islam.

Therefore, Muslims must establish the Islamic State, for Islam would not have an influential presence without it, and their country would not become an Islamic homeland unless it is ruled by the Islamic principles.

Introduction of State: According to the modern scholars, the state is a concept of political entity and a moral reality which exists where a number of populations living in a definite territory and are unified under a government which, in internal matters, is the organ for expressing its sovereignty and, in external matters, is independent of other government.

In this regard Dr Mustafa Kamal says ${ }^{5}$ : "State is a territory where a group of well organized people live having sovereignty".

Dr Abdul Karim Zaidan says that "whatever the definition is given, the state must have certain elements as follows ${ }^{6}$ :

1. Well- organized population;

2. Under a universal system;

3. Living in a definite territory;

4. Having sovereignty;

5. Being free from any external influence;

However, Islamic state is neither like the conventional state, nor it is one which is ruled by Muslims rather it must satisfy the demand of 
Islamic Shari'ah first. So we may identify the fundamental elements of an Islamic State as follows:

1. Administration according to the revelation (Al-hukm bi ma anjala Allaha): It is, no doubt, a distinguishing element for an Islamic State. Allah (SWT) says in this regard: "So judge among them by what Allah has revealed, and follow not their vain desires, diverging away from the truth that has come to you". (sura al-Maidah: 48). If we look at the state of Medina and analyse this we find that it was direcly related with this revelation.

2. Well-organized population (al-ra'iyah/al sha'b): This wellorganized population is the second important element on whom the law of Allah be implemented, laws of the state are executed. According to citizenship rule of Islam, they are divided into two types - Muslims who have belief in the state ideology and non-Muslims who are not believers in the state ideology. In the state of Median, the whole population both Muslim and non Muslims, were organized in the light of Charter of Medina.

3. A definite territory (al-Dar/ al-Eqlim): This definite territory surrounded by border line is that where the population stay and laws of the state are executed. It is in relation to Islamic Ideology of two types - Islamic (Darul Islam), where Islamic Shari'ah is practiced, and nonIslamic (Darul Kufr), where Islamic Shari'ah is denied and rejected. That state of Medina, being a city state, had a fixed area and ultimately for the victory of Islam, this territory expanded, and a broad area had come down its grip.

4. Responsible authority (Ulul amr): This responsible authority is termed in Islamic Political Sience as 'Khalifah', 'Amirul Mu'minin' or 'Imam'. These refer to the head of the government. The title 'Khalifah' once again resumed with ascension of Abu Bakr Siddiq as the first head of the state of Madina. He is better known as Khalifa Abu Bakr, followed by Umar b. Khattab, Osman b. Affan and Ali bin Abi Talib. Abubakr ${ }^{\circledR}$ termed himself to be the Khalifah or successor of the Prophet (Sm) (Khalifatu Rasulillah) and then Umar ${ }^{\circledR}$ being in-charge of Khilafah was known as successor of the successor of the Prophet(Sam) (khalifatu Khalifati rasulillah), and later he chose for himself the title 'Amirul Mu'minin' and then Usman ${ }^{\circledR}$ used the word 'khalifa' directly for him. Ali ${ }^{\circledR}$ was known with 'Al-Imam' for the first time in the history of khilafah. It may be pointed out that in whatever 
form the word is used for the post of Khalifah - 'Amirul Mu'minin, Imam, President or Prime-minister or even Sultan in primitive time-it is actually vicegerency of Allah for the establishment of 'al-Din alIslam' on the method of the Prophet (Sm).

\section{Sovereignty as an element of State: a criticism}

Sovereignty is considered for modern national states to be a very important political concept. It is supposed to be the most essential quality of a state. The organized people of a territory are recognized as a state only when they enjoy sovereign authority.

If the territory is governed by any authority from outside, it can not be called a state even if it is a vast territory with a huge population organized under a strong Government.

According to Mawlana Mawdudi, in the definition of state, 'Having Sovereignty' means that the territory must be independent from any outside authority. If sovereignty of the state means independence, it is quite reasonable.

But Mawdudi does not consider independence and sovereignty as synonymous. According to him sovereignty can not belong to state, because it belongs to Allah alone. He emphasizes on the universally accepted definition of law as "Will of the Sovereign". He strongly argues that only Allah is capable of making balanced, correct, eternal, efficacious, beneficial laws. He writes:

"The belief in the Unity and Sovereignty of Allah is the foundation of social and moral system propounded by the Prophets. It is the very starting-point of the Islamic political philosophy. The basic principle of Islam is that human being must, individually and collectively, surrender on God all rights on overlordship, legislation and exercising of authority over others. No one should be allowed to pass orders or make comments in his own right and no one ought to accept the obligation to carry out such command and obey such orders. None is entitled to make laws on his own authority and none is obliged to abide by them. These rights vest in Allah alone.?

"The authority rests with none but Allah. He commands you not to surrender to any one save Him. This is the right way (of life)" (AlQur'an 12:40) 
"They ask: 'have we also got some authority'? Say; 'all authority belongs to Allah alone' "(3:154)

According to this theory, sovereignty belongs to Allah. He alone is the lawgiver. No man, even if he be a Prophet, has the right to order others in his own right to do or not to do certain things. The Prophet himself is subject to Allah's commands. "I do not follow anything except what is revealed to me." (6:50)

"They are the people unto whom We gave the Scripture and Command and Prophethood" (6:90)

"The Qur'anic concept of sovereignty is simple. God is the Creator of the universe. He is its real Sustainer and Ruler. It is His Will that prevails in the cosmos all around. As all creation is His, His command should also be established and obeyed in man's society. He is the real Sovereign and His Will should reign supreme as the Law." 8

\section{Vicegerency: the appropriate status of human being}

Khilafah, man's essential assignment, means implementing Allah's intent on Earth and practicing His rules. This confers authority upon men and women to carry out their entrusted task: observe what Allah enjoins and refrain from what He prohibits. As the Prophet said, in hadith narrated by Thawban: "He who enjoins ma'ruf and prohibits munker is the khalifah of Allah, the Qur'an and the Prophet on the Earth."

Khilafah means succession or representation, and Khalifah means successor or representative. In Islamic constitutional law, khilafah refers to statehood and Kahlifah refers to the head of the government. That is why the title 'khalifah' was used with the election of Abu Bakr Siddique as the first head of the state of Medina.

In Islam, Khalifah means the person who would implement the will of Allah on earth as His deputy or representative. As Allah's representatives we the human beings should carry out the Will of Allah on His behalf as a trust (Amanah). And the Caliph (Head of Muslim administration or governments) are simply representatives of Allah for the establishment of as-Din (the way of life ordained by Allah) in the method of the Prophet (SM).

Allah is the only Sovereign and we are His slaves and subjects. Allah will not come down on the earth to execute His sovereignty; but we, as 
the representatives of Allah on earth, are to make it a safe place for our living.

So, man's designation is khalifah and his mission is to establish khilafah. It is indeed, a great honor and prestige to a man to be the khalifah or representative or vicegerent of Allah (Swt) among all of His creatures. And such honor is given to him only, not even to the angels. As a vicegerent of Allah, he must do as Allah commands him to do. But he has a choice to either obey or disobey Him. And because of this freedom of choice, he will be accountable on the Day of Judgment.

Allah (Swt) states in the holy Qur'an:

"Allah has promised those among you who believe and do righteous deeds, that He will certainly grant them succession to (the present rulers) in the land, as He granted it to those before them, and that $\mathrm{He}$ will grant them the authority to practice their religion which $\mathrm{He}$ has chosen for them (i.e. Islam)." (Sura Nur, 24:55)

According to Mawlana Mawdudi, this ayah, revealing the theory of State in Islam, has disclosed an important point that Allah (SWT) has promised this vicegerency for all who have beliefs in Him, which is termed as popular vicegerency ${ }^{10}$ in Islamic politics contrary to the Popular Sovereignty in traditional political thinking. So sovereignty as an element of state is not supported in Islam and Islamic State as well.

\section{Islamic State and its basic principles}

An Islamic state is one which runs according to the principles of Islam. But a state is said to be Islamic not merely because the majority of its population are Muslims.

An Islamic State can be defined in this way, "It is one which is governed by the Muslims and run according to the principles of Islam". Islam wants to fashion our entire life according to the principles of individual and social behavior revealed by Allah and practiced by His Prophet Muhammad (SM). The Qur'an declares: "O you who believe! Obey Allah and obey the Messenger [Muhammad $(\mathrm{SM})$ ], and those who are in authority. If differ anything amongst yourselves, refer it to Allah and His Messenger, if you believe in Allah and in the Last Day. This is better and more suitable for final determination. (Sura An-Nisa, 4:59) 
This Ayah discloses the five basic principles of an Islamic state. These are:

1. Allah (SWT) is the sovereign lawgiver Who must be obeyed without any question;

2. Prophet Muhammad (SM) is also to be obeyed unconditionally as he is Allah's Vicegerent;

3. All other legal authorities will be obeyed conditionally; so long as they obey Allah and the Prophet. None can be obeyed in violation of the clear commands of Allah and His Prophet (SM);

4. Dispute is allowed with all other authorities except Allah and His Messenger. Government and people are two parties. In case of any dispute between them the matter must be referred to Allah (the Qur'an) and to His Messenger (in his presence) or to the Sunnah of the Prophet (in his absence); and

5. There must be a recognized body (Judiciary) to pronounce verdict according to the holy Qur'an and the Sunnah. And this body must enjoy complete independence to give judgment even against the government if necessary. ${ }^{11}$

In other words, the state is treated to be an Islamic state that possesses the following features:

a. No person, class or group, not even the entire population can claim sovereignty. Allah alone is the real sovereign; all other are merely His subjects.

b. Allah is the real law giver and the authority of absolute legislation vests in Him. No body can modify a law which Allah has laid down, nor he can desire to effect or change in Allah's Divine laws.

c. The government of such a state will be entitled as a political agency to enforce the laws of Allah among the people of its territory. ${ }^{12}$

\section{Islamic State of Medina An Overview}

If we look at the content of the Charter of Medina, which was promulgated soon after the Prophet arrived at Medina in the year of $623 \mathrm{CE}$, we will see that it indicates the inherent objective of the Constitution of Madina was the declaration of Medina as an Islamic city state. In this Islamic state all the people enjoyed equal rights and 
privileges, despite their religious differences, all strived and worked diligently for the development of their city ${ }^{13}$. One of the cardinal principles of Islam is to believe in all the Prophets of Allah (SWT) who were sent to preach the truth prior to Muhammad (SM). This principle alone is enough to fortify the brotherhood of humanity. Muhammad had realized from his experiences in Makka, what it had been like to live in a city where one could not enjoy the freedom of religious belief.

The Constitution of Madina provided Prophet (SM) with power for the declaration of war and peace. According to the Charter of Madina, nobody from Ummah is allowed to declare a war or to take part in it without the permission of Muhammad (SM). Thus as Head of the state, the Prophet (SM) was also the Commander-in-chief of the armed forces of Madina.

The Prophet (SM) was the head of the judiciary together with all other branches of his government. It was very much needed and compulsory for the Prophet to be the head of all heads. Because, for taking decision on any matter the Prophet (SM) was dependent on the revelation. This was the reason for him to be the head of all three organs. Provincial governor was called Al-Wali. There were Kazi (judge) independent of Wali. Moreover, it was needed for the Prophet to be the model for the Ummah as chief executive and chief justice.

After the death of the Prophet (SM), Abu Bakr (RA) succeeded the Prophet to be the head of the state of Medina. During his khilafah, for the first time, he separated the judiciary from the executive organ of the state at the Center and appointed Umar bin Khattab as the chief justice. ${ }^{14}$

\section{State Ideology and Belief}

There are countries which identify and fix their state ideology. Such as Turkey, for example, identified secularism as the only ideology. ${ }^{15}$ Some countries may fix Islam as the state ideology. Bangladesh in its constitution of 1972, fixed four ideologies, such as Secularism, Socialism, Bangali Nationalism and Democracy. Subsequently in 1978, a major amendment took place in the state ideology whereby secularism was dropped and replaced by the absolute trust and faith in Allah-Almighty; socialism was replaced by social justice and Bengali Nationalism by Bangladeshi Nationalism. Since the objective of an Islamic state is totally different from a non Islamic state, therefore, the ideology of this state is Islamic Monotheism or Tawhid which may be 
focused in the political side of our life with the word 'sovereignty of Allah'.

\begin{abstract}
A brief history of Ideological state
One of the most progressive social ties is that of doctrine and dogma. The people who believe in one religion or one ideology are united by it and form one community which is a society having a common goal and a common policy. An ideological tie may be so powerful and effective that it may overshadow all other ties. And their laws would emanate from the tribal chief's willing or group's opinion or the customs or religious laws. In this regard Gettel says ${ }^{16}$, "They assert that custom and popular consent, as well as definite political authority create law".
\end{abstract}

Other writers assert that the laws of Allah (SWT) or the fundamental principles of justice which embodied in the natural law or which result from social nature of man are law'. Gettel also says, "In the main these objections result from confusing the sources from which legal principle has sprung and the sanction that enforces them. It is true that custom was for a long time the only sources of law and is still an important influence".

From the above discussion we can realize that the conventional political thinkers have no clear conception on the beginning era of human society. Their society was limited in tribe, nation and country.

In this regard, Syed Mawdudi says, "In the ancient time people were familiar with tribal and national states, but never were they acquainted with an ideological state where every one has equal participation regardless of their color, tribe and nation".

Mawdudi also says, " the Christianity had had an obscure idea about that ideological state but they failed to get a clear one on which a state may be established. A feeble sun shine of ideological state was seen in the French renaissance but within a short period of time it had been turned into and sunk in the idea of nationalism. Communism had preached this idea of ideological state particularly and tried its best to establish a state on the basis of its ideology but finally it was also sunk in the sea wave of nationalism". ${ }^{17}$

The idea of an ideological state presented in the Holy Qur'an, clearly denies nation and nationalism as the basis of state and addresses the whole humanity equally regardless of their color, tribe or territory. 
This kind of state presents an ideology towards the whole humanity and assures them if they accept it, they will be successful and their prosperity will be assured. The believers in this ideology will participate in the management of state affairs equally.

\section{Concept of welfare state}

It is a universally accepted concept that 'welfare state' is the ideal state. It means such a state where every citizen feels happy. None suffers from any want of necessities of life. None suffers from any kind of injustice in social, political and economic life. It is a state in which peace, tranquility and happiness prevail. Those states, which claim to be welfare states, are highly developed in science and technology. Naturally, they are supposed to be able to utilize the inventions for enhancing happiness. But as they are not guided by divine knowledge, the inventions are misused resulting in the suffering of the people in many ways. If the leaders of western civilization were guided by divine knowledge, they could save their people from the illeffects of immoral use of inventions. ${ }^{18}$

The welfare function of the Islamic state was particularly stressed by the Prophet when he stated, "Any ruler who is responsible for the affairs of Muslims but does not strive sincerely for their well- being will not enter Paradise with them." The Companions of the Prophet clearly appreciated this welfare role of the Islamic state as is evidenced by numerous utterances of the early Caliphs and their instructions to their Governors. 'Umar, the second Caliph, wrote to Abu Musa, the governor of a province, "The best of men in authority is he under whom people prosper and the worst of them is he under whom people encounter hardships" ${ }^{19}$.

So, if the effort of establishing an ideal state succeeds in any country, it may exemplify the real welfare state.

\section{Relationship of the state organs}

The state may be termed as a political system which functions as the whole of the social system with its set boundaries, goals, processes etc. Thus the state as a political system consists of many sub-systems and these sub-systems may be treated as its organs. The main organs or sub-systems are: a) the executive b) the legislative and c) the Judiciary. 


\section{The Executive}

Generally executive refers to the ruling class of a state. The term executive may be used in two senses. In its wider sense, it means all government officials except those acting in legislative and judicial capacity. But in its narrow sense, the term refers only to the heads of the government, the chief executive or head of the state, his ministers and advisers.

The Qur'anic term for executive is 'ulil amr' which means authority. Obedience to ulil amr is made obligatory for the Muslims after the obedience of Allah \& His Messenger. As it is said,

"O you who believe! Obey Allah and obey the Messenger of Allah and those charged with authority among you" (Sura Al Nisa, 4:59)

Four basic things are mentioned in this ayah. These are as underneath.

\section{Obedience of Allah;}

2. Obedience of the Messenger of Allah;

3. Obedience of those who are made authority or responsible to carry out some kind of responsibilities; and

4. They should be among you - means among the Muslims;

The term 'responsible' is very wide with several connotations. For example, he is in the case of an organization, the party leader, in the case of judiciary, he is the chief justice, in the case of parliament, he is the leader of the house, in the case of army, he is the chief staff of army, in the case of business, he is the business leader, in the case of sports, he is the team leader and in the case of educational institution, he is the principle or vice-chancellor and in the case of a family, he is the father as the head of the family. In the case of a state, he is the chief executive of the state or government. In all those cases command of the ulil amr is to be obeyed so long as such command is in accordance with the Shari'ah law. However, obedience of ulil amr is conditional unlike the obedience of Allah and His Messenger.

Moreover, when the term refers to the Head of the state or government of an Islamic state, he must be a Muslim based on the Qur'anic word Ulil Amri Minkum. But a non-Muslim can be appointed in other portfolios of the government like Minister, Ambassador, and Secretaries etc. Such was the practice of the Prophet (SM). He sent 
Amr ibn al Darimi, a non Muslim, as an Ambassador to Negus, the king of Ethiopia on behalf of the Prophet (SM). Umar bin Khattab appointed a Greek Christian as his chief accountant. ${ }^{20}$

As regards the selection of right and qualified person to the right place, al Qur'an commands:

"Allah Ta'ala commands you to render back your trust to those to whom it is due. (Sura Al Nisa 4:58)

The head of an Islamic state elected by the people would be supreme leader of the people. The holy Prophet (SM) enjoyed the same status in the Islamic state of Madina. After his death, all the rightly guided Caliphs maintained the position.

\section{Functions of the Executive:}

The functions of the Executive depend on the nature of the government. In an Islamic state, the functions of the Executive, in brief, are as follows: ${ }^{21}$

1. To manage all sorts of activities for the attainment of the purposes of the state;

2. To protect the country from the foreign aggression;

3. To maintain the foreign relations;

4. To perform the financial functions;

5. To maintain law and order and run the administration;

6. To establish and maintain the publication and broadcasting department and communicate the local and global news to the citizens fairly and impartially; and

7. To appoint Hisbah (ombudsman) for supervising the activities of all the branches of government.

So the Executive of a state is responsible for all the affairs of the state and its citizens. Islamic thinkers opine that the main duty of the executive in an Islamic State is the 'Custodianship of religion and management of State affairs'. 


\section{The Legislative}

It is the law making body of a state. One of the functions of legislature is to consult with other experts in the relevant field of making law. As Allah (swt) says,

(O' Prophet) "Pass over (their faults) and ask for Allah's forgiveness for them and consult in affairs with them, then when you have taken a decision (based on consultation) put trust in Allah." (Sura Al Imran, $3: 159)$

With regard to this, the Sunnah of the Messenger of Allah is as follows.

"Ali b. Abi Talib (RA) reported that, I asked the Messenger of Allah, how do we run our affairs in case of not tracing their solution in al-Qur'an and alSunnah? The Prophet said, "It is to be done by calling pious people and by their collective opinion but not by the opinion of a single man". ${ }^{22}$

Legislation in an Islamic state should be within the limits prescribed by the Shari'ah. The injunctions of Allah and His Prophet are to be accepted and obeyed and no legislative body can alter or modify them or make any new laws, which are contrary to their spirit ${ }^{23}$.

Great scope would still be available for legislation on questions not covered by any specific injunctions of the Shari ' $a$ h, and the consultative body or legislature is free to legislate in regard to these matters.

In this respect Maulana Abdur Rahim states that there is no function of legislating in its true sense as in conventional political system, but searching, codifying of the injunctions of Allah (SWT) in the light of the Sunnah of Prophet Muhammad (SM) as well perusing the way and occasions to imply these injunctions. ${ }^{24}$

Hence there are four aspects of bringing the injunctions of Allah (SWT) into application. These are as follows.

1. Making of laws - this function is for Almighty Allah alone.

2. Searching, codifying and seeking way to imply the injunctions it is for the Shura.

3. Executing the laws - the executive body is duty bound for this. 
4. On the basis of the Islamic laws, solving the conflicts and contradictions among the people and criminal punishment - it is duty bound of the judiciary.

\section{Shura or Consultation}

The term 'Shura' is derived from shour means consultation in order to arrive at a collective decision.

The word 'Shura' is used in the holy Qur'an to denote a decisionmaking process among the people. Regarding this Allah says, "They conduct their affairs by mutual consultation ${ }^{25}$ " (Sura al Shura 38)

So, Shura or consultation in the Islamic political system is so central and fundamental that without it the whole political process is rendered null and void and of no effect. It is as such that even the Prophet (SM) with his special position and direct access to Allah did consult his companions.

Because, he was commanded by Allah as saying, "and consult them in the affairs. Then when you have taken decision, put your trust in Allah, certainly Allah loves those who put their trust in Allah ${ }^{26 "}$ (Al-Imran: 159). It is clear to us that 'Shura' is indispensable for the Islamic state. It composed of the learned and sagacious men who are elected by the people.

In this respect Allah enjoins, "Ask of those who know scripture if you know not". (Surah Ambia: 7). Hence the body of the Shura must be learned and sagacious and Allah fearing in all spheres of life ${ }^{27,}$

Besides, it is an honor for them that they are asked of all sorts of Islamic laws because they are appointed for delivering Islamic laws regardless whether it is concerning to collective or state affairs ${ }^{28}$.

In addition to this, since the Qur'an and the Sunnah are two main sources of Islamic laws, the body of the Shura must be able to do Ijtihad. Otherwise, it would be quite impossible for them to perform their duty precisely.

\section{The Judiciary}

Justice in its true sense can only be materialized through judiciary. How good the legislative and executive are, cannot be seen in its optimistic pace without the proper and effective role of judiciary. 
Human intellect is not adequate to provide all that appropriate to the society on his own, for he is unaware of all beneficial and harmful consequences. In this concern Allah (SWT) says, "You not know which out of them is nearest in profit to you ${ }^{29 "}(4: 11)$.

In this context Allah (SWT) further says, "Indeed, we have sent our messenger with clear proofs, and revealed on them the scripture and the balance (justice) that mankind may keep up justice. And we brought forth iron wherein is mighty power as well as many benefits for mankind. That Allah may test who it is that will help Him and His messenger in the unseen. Verily Allah is All strong All mighty ${ }^{30} "$ (Al Hadid: 25).

This indicates that the aim of sending the messengers of Allah with clear signs and sending the scriptures down with them is that the people would uphold justice. If men were able to achieve justice through their intellect there would have no need for the revelation. Emphasizing on judiciary Allah says, "But no, by your Lord, they can have no faith until they make you judge in all disputes between them and find in themselves no resistance against your decisions and accept with full submission ${ }^{31 "}$ (An Nisa:65).

This duty, to establish an Islamic judiciary is not only to the messengers but also to all believers.

\section{Administration of justice}

The Qur'anic term 'Qada' which means administration of justice. It also indicates that is to give an order and judgment. It is a system where the act of deciding or passing decisions on something is rooted in.

- Defining judiciary Maulan Abdur Rahim mentions, Judiciary is an institution, which settles all sorts of disputes and disagreements of litigates ${ }^{32}$.

- It is referred to in Qamus al Muhit, to settle the disputes among the people with the Shri'ah.

- Allama Saraksi says, "Judiciary is to judge among the people hearing the litigants and knowing the true happening and apple of discord" ${ }^{33}$.

In this sense there are numerous verses in the Qur'an, for example, "But when comes the commandment of Allah, the matter will be decided with truth and the followers of falsehood will then be lost ${ }^{34}$, (40:78). 
"It is not for a believer, man or woman, when Allah and his messenger have decreed a matter that they should have any option in their decision $^{35 "}$ (al-Ahzab:36).

"And for every Ummah there is a messenger. When their messenger comes the matter will be judged between them with justice and they will not be wronged ${ }^{36}$ " (Sura Younus: 47).

From above Qur'anic expression it is clear that judiciary is a system of divine laws through which all sorts of disputes and disagreements are settled and all kinds of injustices are uprooted.

The judicial system is not new in Islam rather it was established fourteen centuries ago by the Prophet Muhammad (SM) where justice and truth was perpetuated.

So there is no room of doubt that there could be any injustice in an Islamic state. When and wherever in any part of the world Islamic system was established, the people simply not only witnessed but also enjoyed the peace, safety and justice that were never witnessed in any other system in the world. In this point Allama Abul A'la al Maududi states, "The teachings of Islam are eternal, because they have been revealed by Allah Who knows all the present, past and future and Who Himself is eternal. It is the human knowledge that is limited. It is the human eye which can not see into dim vista of the future. He is God Whose knowledge is above all the limitations of time and space ${ }^{37,}$.

\section{Principle of Islamic Judiciary}

The fundamental principles of Islamic judiciary are:

- It is not placed under the control of the executive, and

- It derives its authority directly from the Shari'ah and is answerable to Allah.

The judges will obviously be appointed by the Government but, once appointed, will have to administer justice impartially according to the law of Allah. All the organs and functionaries of the Government should come within their jurisdiction. Even the highest executive authority of the Government will be liable to appear in a court of law as a plaintiff or defendant ${ }^{38}$. 


\section{Purpose or aim of administration of justice}

Purpose or objectives of Qada or administration of justice are as follows ${ }^{39}$ :

a. To protect the weak and punish the wrong doers in the society according to the rules revealed by Allah to His Prophet (SM);

b. To do justice with a view to the establishment of peace on the earth, concord among humanity, advancement of society and safeguard of social as well as human interest;

c. While doing justice, to be witness of Allah (SWT);

d. To pass judgment freely and fairly even though it goes against close relative like parents, children or it goes against one's own self and against rich or poor; and

e. To discharge the duties of khilafah as imposed by Allah (SWT).

\section{Salient Features of an Islamic Ideological state}

The discussion mentioned above on the basic points of Islamic State, its necessity, principles and organs etc. clarifies the matter that an Islamic State is not different from an ordinary modern national state in its structural or systematic formation but the belief and action in accordance with that belief have made it completely separated from any other non Islamic or secular state. Some salient features of an Islamic State are mentioned below:

\section{It is based on Islamic belief and ideology}

Islam did not come to its existence to be dominated and hegemonised under any other system of life, because no system of life can survive and flourish under another order. A mere theoretical religion can do so. But no Prophet preached Islam as a religion only. None of them was ready to pay allegiance to any other man made system of life. Qur'an says, It is He (Allah) Who has sent His Messenger with the guidance and the true code of life with a view to making it victorious over all other codes. Allah is sufficient as witness to that. (Sura al-Fath: 28). Therefore, if we sincerely and faithfully want to follow Islam, we must strive to uphold its supremacy over all other codes. ${ }^{40}$ The State based on Islamic Shari'ah and ideology always plays a role conducive to preaching Islamic tenets and ideology. Philosophers opine that state and Islam are integral part to each-other and without religion a state will turn to a complete fiasco and anarchy. Similarly, religion without state power can not leave any influence on the citizen of the state. 


\section{It denies Secularism completely}

Secularism is absolutely incompatible with Islam. It is ridiculous from Islamic point of view to believe that Allah is to be obeyed in private life alone and $\mathrm{He}$ is incapable of guiding our collective life. The followers of other religions are compelled to think in that line as they feel that their scriptures are inadequate to guide human affairs. Diametrically opposed is the attitude of Islamic scholars. They are confident that the Holy Qur'an and the Sunnah are meant to deal with all aspects of human life. The believers in Secularism may, out of ignorance, consider Islam to be a mere religion. But it is impossible for a conscious Muslim to be secular. The only honorable alternative to the so-called sincere 'Muslim Secularist' is to declare themselves nonMuslim, as Muslim Secularist is a ridiculous misnomer. ${ }^{41}$

\section{Difference between Islamic and Secular State}

An Islamic state is essentially an ideological state, and is thus completely different from a national state. This statement of Syed Mawdudi lays the basic foundation for the political, economic, social and religious system of all Islamic countries that implement the Islamic law. Mawlana Mawdudi summarizes the basic differences between Islamic and secular states in the following way.

1. An Islamic State is ideological. People who reside in it are divided into Muslims, who believe in its ideology and non Muslims who do not believe in its ideology.

2. Responsibility for policy and administration of such a state "should rest primarily with those who believe in the Islamic ideology." Non Muslims, therefore, cannot be asked to undertake or be entrusted with the responsibility of policymaking in ideological matters.

3. The Islamic state is bound to distinguish between Muslims and non-Muslims. However, the Islamic law (Shari'ah) guarantees to non-Muslims certain specifically stated rights beyond which they are not permitted to meddle in the affairs of the state because they do not subscribe to its ideology. But once they embrace the Islamic faith, they become equal participants in all matters concerning the state and government. ${ }^{42}$

\section{State Authority}

In addition to establishing its structure solely upon Islam, the security of the Islamic State must be rested in the hands of the Muslims and not 
with any other entity, state, or power. The State should not depend on any other foreign entity or force for its security. Complete authority over its internal affairs and its territory must reside exclusively with the state and the Muslim Ummah.

Referring to the qualities of having the authority of Islamic State Allah says, "Allah has promised those among you who believe and do righteous good deeds that he will certainly grant them succession in the land, as he granted it to those before them and that he will grant them the authority to practice their religion which he has chosen for them and he will give them surely in change a safe security after their fear. They worship Me and do not associate anything with Me. But whoever disbelieves after this they are the Fasiqin ${ }^{43}$ " (Surah An Nur: 54).

Allah also says elsewhere in the Qur'an, "Allah will not make for the Kafir a way over the Muslims ${ }^{44}$ (Surah an Nisah: 141).

Making a non-Muslim govern the Muslims means giving him a way over the Muslims and this has been denied by Allah (SWT). As such, the Ayah is a prohibition for Muslims to allow a non-Muslim to govern them.

In this regard, Allah (swt) has commanded us, "O you who believe! do not ally with My enemy and your enemy, do not grant them your gratitude because they rejected the truth you believe in ${ }^{45} "(60: 1)$.

\section{Accountability of the ruler and the ruled}

In an Islamic State, the state authority or the government is responsible firstly to Allah and then to people. The state authority is elected by the people to exercise powers on their behalf. We must remember here that both the ruler and the ruled are the Khalifah of Allah and the ruler shall have to work for the welfare of the people according to the Qur'an and Sunnah. A ruler is a servant of the people of Islam. Both the ruler and the ruled will appear before Allah and will be accounted for their actions on the Day of Judgment. The responsibility of the ruler is heavier than that of the ruled. Rulers and ruled are subject to the same law and there can be no discrimination on the basis of position, power or privilege, as we see the discrimination in the conventional political system. Especially in America and Russia, there are deferent laws for colors, races and classes. Islam stands for equality and adheres to this principle in the social, economic and political realms alike. 
This accountability of government is related not only with the Day of Judgment but also with the present life. Any ordinary citizen of an Islamic state has the right to ask any question on any matter to the ruler and the government. This accountability controls the ruler and ruled to transgress the limit of Shari'ah and help them to submit themselves to the will of Allah. For this reason a ruler in Islam can never be a lord of people but vicegerent of Allah and servant of the nation.

It is a democratic state completely subordinate to Islamic law Democracy in its real sense is practiced in Islamic State. Legislation by Shura means democratic system of government that opposes autocratic system. This is the dominant principle of Islamic system of government. In this respect, the political system of Islam is a perfect form of democracy - as perfect as a democracy can ever be. Of course, what distinguishes Islamic democracy from Western democracy is that the latter is based on the concept of popular sovereignty and the former rests on the principle of popular vicegerency (khilafat). In western democracy, the people are sovereign, in Islam sovereignty vests in Allah and the people are His Caliphs or representatives. In the latter, the people make their own laws; in the former, people have to follow and obey the laws (Shari'ah) given by Allah through His prophet. In the latter the government undertakes to fulfil the will of the people and in the former the government and the people, who form it, fulfil the purposes of Allah. In brief, western democracy is a kind of absolute authority which exercises its power in a free and uncontrolled manner whereas the Islamic democracy is subservient to the Divine Law and exercises its authority in conformity with the injunctions of Allah and within the limits prescribed by Him. ${ }^{46}$ This kind of Islamic democracy is termed by Sayed Mawdudi as 'Theo-Democracy'. ${ }^{47}$

This table coming bellow may clarify and identify the Islamic Ideological State at a glance. 
IIUC Studies, Vol. 7

Table-01

Modern National State and Islamic Ideological State: a comparison

\begin{tabular}{|c|c|c|}
\hline Guiding Criteria & Modern State & Islamic State \\
\hline Character & $\begin{array}{l}\text { Secular, Democratic or } \\
\text { National }\end{array}$ & $\begin{array}{l}\text { Ideological, Democratic } \\
\text { and welfare }\end{array}$ \\
\hline Basis & $\begin{array}{l}\text { Sovereignty of people, } \\
\text { Secularism, and capitalism }\end{array}$ & $\begin{array}{l}\text { Unity of Allah, Resalat } \\
\text { and Khilafat }\end{array}$ \\
\hline $\begin{array}{l}\text { Status of } \\
\text { population }\end{array}$ & $\begin{array}{l}\text { Sovereign Authority/ } \\
\text { popular sovereignty }\end{array}$ & $\begin{array}{l}\text { Vicegerent of Allah/ } \\
\text { popular vicegerency }\end{array}$ \\
\hline Supremacy & $\begin{array}{l}\text { Supremacy of people is } \\
\text { claimed as sovereign } \\
\text { authority }\end{array}$ & $\begin{array}{l}\text { Sovereignty of Allah and } \\
\text { supremacy of Islamic } \\
\text { Shari'ah }\end{array}$ \\
\hline $\begin{array}{l}\text { Relation between } \\
\text { state and religion }\end{array}$ & $\begin{array}{l}\text { Separation of state from } \\
\text { religion or freedom from } \\
\text { religion completely }\end{array}$ & $\begin{array}{l}\text { Religion and state are } \\
\text { same and intertwined. }\end{array}$ \\
\hline \multirow{3}{*}{ Source of law } & \multirow{3}{*}{$\begin{array}{l}\text { Parliament, verdict or } \\
\text { ordinance }\end{array}$} & $\begin{array}{l}\text { Al-Qur'an, Al-Sunnah } \\
\text { (primary source) }\end{array}$ \\
\hline & & $\begin{array}{l}\text { Ijma' and Qiyas } \\
\text { (Secondary Source) }\end{array}$ \\
\hline & & $\begin{array}{l}\text { Al-Urf, al-Istihsan, al- } \\
\text { Masalih al-Mursalh etc } \\
\text { (additional Secondary } \\
\text { source) }\end{array}$ \\
\hline $\begin{array}{l}\text { Vote for electing } \\
\text { chief Executives }\end{array}$ & Regarded as right of people & $\begin{array}{l}\text { Regarded as trust and } \\
\text { right as well }\end{array}$ \\
\hline Accountability & $\begin{array}{l}\text { Government are accountable } \\
\text { to people }\end{array}$ & $\begin{array}{l}\text { the government is } \\
\text { accountable firstly to } \\
\text { Allah and then to people }\end{array}$ \\
\hline $\begin{array}{l}\text { Power of } \\
\text { legislation }\end{array}$ & $\begin{array}{l}\text { May legislate whatever they } \\
\text { wish in any time. }\end{array}$ & $\begin{array}{l}\text { Legislation must be } \\
\text { within the limits } \\
\text { prescribed by the } \\
\text { Shari'ah. }\end{array}$ \\
\hline Judiciary & $\begin{array}{l}\text { In theory it is free from } \\
\text { executive not in practice }\end{array}$ & $\begin{array}{l}\text { Completely Independent } \\
\text { in theory and practice }\end{array}$ \\
\hline Economic System & $\begin{array}{l}\text { Controlled by some } \\
\text { powerful capitalists }\end{array}$ & $\begin{array}{l}\text { Based on System of } \\
\text { Zakah and checked and } \\
\text { balanced by it. }\end{array}$ \\
\hline $\begin{array}{l}\text { Administrative } \\
\text { principle }\end{array}$ & $\begin{array}{l}\text { Domination of capitalist } \\
\text { anarchism }\end{array}$ & $\begin{array}{l}\text { For belief in } \\
\text { accountability in the day }\end{array}$ \\
\hline
\end{tabular}




\begin{tabular}{|l|l|l|}
\hline & & $\begin{array}{l}\text { of judgment a just } \\
\text { administration is found }\end{array}$ \\
\hline Individual Liberty & $\begin{array}{l}\text { Individual liberty is said to } \\
\text { be recognized but in a } \\
\text { socialist state it is not } \\
\text { recognized, religious } \\
\text { freedom is not tolerated at } \\
\text { all. }\end{array}$ & $\begin{array}{l}\text { Right to freedom of } \\
\text { association, assembly } \\
\text { and speech are highly } \\
\text { ensured in its optimum } \\
\text { lavel. }\end{array}$ \\
\hline Rule of law & $\begin{array}{l}\text { Malpractice of power and } \\
\text { injustice }\end{array}$ & $\begin{array}{l}\text { Equality before law and } \\
\text { justice }\end{array}$ \\
\hline
\end{tabular}

\section{Conclusion}

From the above discussion it may be said that the modern national states have got much development in its structure, formation and in external beauties. This historical development is natural. Islam can never oppose it. But the main point of distinction lies in belief and thinking. The belief in the Unity and Sovereignty of Allah is the foundation of social and moral system propounded by the Pophets. It is the very starting point of the Islamic political philosophy. The basic principle of Islam is that human beings must, individually and collectively, surrender to Allah. The Prophet of Islam established a model of religio-socio-politico-economic society where Qur'anic laws were implemented. The duty of an Islamic state is to establish Salah, Zakah and promote the right and forbid the wrong. (22:41). The state is responsible for the welfare of all its citizens- Muslims and NonMuslims. It must guarantee the basic necessities of all citizens. All citizens of the Islamic state shall enjoy freedom of belief, thought, conscience and speech. Every citizen shall be free to develop his potential, improve his capacity, earn wealth and won such wealth within the limits set by the Qur'an and the Sunnah. A citizen shall enjoy the right to support or oppose any government policy which he thinks right or wrong.

This Islamic state is duty bound to implement the laws of the Qur'an and the Sunnah. The Qur'an strongly denounces those who do not decide their matters by Allah's revelations (5:42-50).

In Fine, it may be concluded that Islamic Ideological State is not a religious state which is opposed by secularism in its long war between Religion and Science. It is actually a full fledged ideal welfare State, not for Muslim alone but for the whole humanity at large. This is not a mythological story. But history bears the witness that most uncivilized people of Arabia within a generation miraculously elevated themselves 
to the position of harbingers of a great civilization. This is an undeniable fact of history.

1. Dr. AL-HILALI, MUHAMMAD TAQI UDDIN and Dr. KHAN, MUHAMMAD MUHSIN (1419A.H) The Noble Qur'an: English Translation of the Meaning and Commentary:

2. DR. AL QARDAWI, YOUSUF, Figh al Dawla, P14.

3 Khllaf, Abdul Wahhab, 'Ilmu Usulil Fiqh, (1986), E20, Beirut: Darul Qalam. P32-34

4 Al Maududi, Abul A'la, (1980) Nizam Al Hayat fi Al Islam, published by Mu'assasa al Risalah, Beirut, P 21.

5 Dr. ZAIDAN, ABDUL KARIM, (2002) Islami Rastra Bebosta, translated by Maulana Abdur Rahim, E 9, Dhaka, Adhunic Prokashoni., P13.

6 Dr. ZAIDAN, ABDUL KARIM, (2002) Islami Rastra Bebosta, P 13.

7 Mawdudi, Syeed Abul A'la, The Islamic Law and Constitution. P136 and 137.

8 Mawdudi, Syeed Abul A'la, The Islamic Law and Constitution. P166

9 Al-Najjar, Abd al-Majid, (2000AC), Virginia: IIIT, P22. this Hadith is stated here referring ' Reported by Al-Muttaqi al-Hindi, kanz al Ummal.

10 Al-Mawdudi, Abul-A'ala, (1967), Nazriyatul Islam Al-Siyasiyah (Theory of State in Islam) Damasque: darul fikr. P 45-46

11 BHUYAN, MOHAMMAD SHAFIUL ALAM, (2007) The Government and Politics in Islam: Dhaka: Noor Publications, P69.

12 KHAN, Md. ANSAR ALI (2006) Legal System of Islam, Dhaka: Kamiub Prokashan Limited, P45.

13 M.A. Wahhab (Winter 1996) Lessons from the Constitution of Madinah, University of Chittagong: Journal of Islamic Administration. P59.

14 Dr. MAHBUBUL ISLAM, A. B.M., (2002), Islamic Constitution: Qur'anic \& Sunnatic perspective:, Dhaka: Professors Publication, P189.

15 Dr. MAHBUBUL ISLAM, A. B.M., (2002), Islamic Constitution: Qur'anic \& Sunnatic perspective:, Dhaka: Professors Publication, . P51. 
16 Gettel, Political Science, P167

17 AZAM, Prof. Ghulam, (2008), Islami Biplobar Path (The way of Islamic revival) Dhaka: Shatabdii Prokashan, P10.

18 AZAM, Prof. Ghulam, ISLAM the only divine code of life, P50)

19 CHAPRA, M. UMAR, The Islamic welfare State and its Role in the economy. (From Net)

20 Dr. MAHBUBUL ISLAM, A. B.M., (2002), Islamic Constitution: Qur'anic \& Sunnatic perspective:, Dhaka: Professors Publication, P 121.

21 KHAN, Md. ANSAR ALI (2006) Legal System of Islam, Dhaka: Kamiub Prokashan Limited. P.65

22 this Hadith is quoted in "Tafsir Ruhul M'a'ani in explaining of suara al shura (42:38)

23 Maulana ABDUR RAHIM, (2000) Al Qur'ane Rastra o Sorker, P157

24 Maulana ABDUR RAHIM, (2000) Al Qur'ane Rastra o Sorker, P157158.

25 Dr. AL-HILALI, MUHAMMAD TAQI UDDIN, (1419A.H) The Noble Qur'an: English Translation of the Meaning and Commentary.

26 Dr. AL-HILALI, MUHAMMAD TAQI UDDIN, (1419A.H) The Noble Qur'an: English Translation of the Meaning and Commentary.

27 Dr. AL-HILALI, MUHAMMAD TAQI UDDIN, (1419A.H) The Noble Qur'an: English Translation of the Meaning and Commentary.

28 Ahmad, Mumtaz, State Politics and Islam, P88.

29 Dr. AL-HILALI, MUHAMMAD TAQI UDDIN, (1419A.H) The Noble Qur'an: English Translation of the Meaning and Commentary.

30 Dr. AL-HILALI, MUHAMMAD TAQI UDDIN, (1419A.H) The Noble Qur'an: English Translation of the Meaning and Commentary.

31 Dr. AL-HILALI, MUHAMMAD TAQI UDDIN, (1419A.H) The Noble Qur'an: English Translation of the Meaning and Commentary.

32 Maulana ABDUR RAHIM, (2000) Al Qur'ane Rastra o Sorker, P220.

33 Maulana ABDUR RAHIM, (2000) Al Qur'ane Rastra o Sorker, P220.

34 Dr. AL-HILALI, MUHAMMAD TAQI UDDIN, (1419A.H) The Noble Qur'an: English Translation of the Meaning and Commentary. 
35 Dr. AL-HILALI, MUHAMMAD TAQI UDDIN, (1419A.H) The Noble Qur'an: English Translation of the Meaning and Commentary.

36 Dr. AL-HILALI, MUHAMMAD TAQI UDDIN, (1419A.H) The Noble Qur'an: English Translation of the Meaning and Commentary.

37 Al Maududi, Abul A'la , (1981) Towards Understanding Islam: (translated by khurshid Ahmad) Islamic Foundation London, P59.

38 Maulana ABDUR RAHIM, (2000) Al Qur'ane Rastra o Sorker, P225.

39 KHAN, Md. ANSAR ALI (2006) Legal System of Islam, Dhaka: Kamiub Prokashan Limited, . P82.

40 Azam, Pro. Gholam, ISLAM the only divine code of life, P58

41 Azam, Pro. Gholam, ISLAM the only divine code of life, P63.

42 Bhuiyan, MD. (2007) Shafiul Alam The Government and Politics in Islam, , Dhaka: Noor Publications,.P61.

43 Dr. AL-HILALI, MUHAMMAD TAQI UDDIN, (1419A.H) The Noble Qur'an: English Translation of the Meaning and Commentary.

44 Dr. AL-HILALI, MUHAMMAD TAQI UDDIN, (1419A.H) The Noble Qur'an: English Translation of the Meaning and Commentary.

45 Dr. AL-HILALI, MUHAMMAD TAQI UDDIN, (1419A.H) The Noble Qur'an: English Translation of the Meaning and Commentary.

46 Maudoodi, Syed Abul A'la, (2005) Islamic Way of Life, Dhaka: Bangladesh Islamic Center, P34.

47 Mawdudi, Syeed Abul A'la, (2005) Islam er Rajnaitik Motobad (Political Doctrin of Islam:, Dhaka: Adhonik Prokashani, P22. 